\title{
Change of Land Registration Policy in Makassar City
}

\author{
Valentini Febriani Bala Lande* \\ Master of Public Administration, Universitas Hasanuddin, Indonesia \\ ${ }^{*}$ Corresponding author. Email: vlande90@gmail.com
}

\begin{abstract}
The reason for this research is to obtain an analysis and description related to the dynamics of land registration policies from PRONA (National Agrarian Operations Project), which have been explained through Ministerial Regulation of ATR/KBPN Number 4 of 2015 to Complete Systematic Land Registration (PTSL) which is confirmed through Guideline of the Minister of Agrarian Affairs and Spatial Planning/National Land Agency Number 6 of 2018 with regards to Complete Systematic Land Registration (PTSL). The research was carried out using a point of view based on the theory of the Advocacy Coalition Framework (ACF), which was initiated by Sabatier and colleagues. The scientific method taken is a qualitative methodology that is carried out using case studies. Hasil yang diperoleh menyatakan bahwa undang-undang mengenai pendaftaran hak atas tanah yang telah diubah tercantum pada Guideline of the Minister of Agrarian Affairs and Spatial Planning/National Land Agency Number 12 of 2017 which examines the Acceleration of Complete Systematic Land Registration (PTSL). The PRONA and PTSL policies are the same policy, namely regarding land adjudication, and there is only a slight increase in the results to be achieved later, which is not only to produce a certificate but also to carry out a mapping process to improve data on land in Indonesia which is grouped into several categories.
\end{abstract}

Keywords: Policy Change, PTSL, Makassar City Land Registration

\section{INTRODUCTION}

The first and most important thing to do when owning land in Indonesia is to make sure the land is registered. The registration of the land owned provides legal certainty that has been guaranteed by the government as stated in Law Number 5 of 1960 article 19 about Agrarian Principles. Then the government also facilitates legal certainty to the community by issuing Unofficial law Number 24 of 1997 with regards to land Registration, in article 3, letter a, the regulation explains the purpose of land registration, namely to provide legal guarantees to landowners as proof of legal ownership. Proof of ownership of land or other rights in accordance with Article 4 is as a Certificate of Land Rights. [1]

Makassar City is one of many regions in Indonesia that implement the PTSL policy. In 2021, the Makassar City National Land Agency will make a free certificate policy with a target of 5.000 certificates with the PTSL policy. The PTSL program in 2020 has been carried out in Manggala urban village. Meanwhile, in 2021, it will be held in two sub-districts in Makassar City, namely in Wajo urban village and Tamalanrea urban village. Each sub-district is given a certain quota, in Wajo sub-district for seven urban villages, while in Tamalanrea subdistrict, there are only two urban villages. Specifically for the Tamalanrea sub-district, the two urban villages are Tamalanrea urban village and Tamalanrea Jaya urban village.

Research on the dynamics of policymaking carried out in the process of implementing public administration with the latest system mostly implements the Advocacy Coalition Framework (ACF) method proposed by Sabatier and colleagues. This method describes the procedures for implementing and adjusting public policies with the specification of the policy subsystem as the main analysis component. ACF focuses on the relationship of each advocacy coalition within a policy system. ACF provides the advantage of being used in interpreting dynamic conditions and conflicts. This means that this method can be used as a mediator between the gap between planning and implementing public policies that occur in social life. [2]

The phenomenon of land policy regarding land registration in Makassar City, which has been previously conveyed, has attracted the author to carry out research entitled "Change of Land Registration Policy in Makassar City". 


\section{LITERATURE REVIEW 2.1. Public Policy}

According to Anderson, states " a purposive strategy followed by an agent or set of agents in managing an issue or matter of concern ". Anderson argues that public policies need to be formulated by someone who acts as an actor (executive, for example, a Presidential Decree) or by a group of people as actors (a combination of executive and legislature, for example, in formulating laws, as well as the judiciary in charge of conducting judicial review of laws), and following the basis of government, actors outside the scope of government are involved in policymaking, namely the private sector, non-governmental organizations, mass media and academics from the university scope. [3] This is used as a series of government decisions in achieving certain goals, such as solving problems that occur based on applicable regulations by forcing (authoritative), which means absolute and all parties are obliged to comply with the rules in the process of solving problems that occur. Therefore, parties who act as actors in public policymaking must clarify the limits of authority in their involvement and the goals to be achieved by these parties.

\subsection{Policy Change}

Policy changes are characterized as major and minor changes in an arrangement subsystem or an administration program. Significant changes allude to changes in center viewpoints, while minor changes allude to changes in auxiliary parts of the public authority's strategies or projects. [4]

Strategy changes can happen in major or minor aspects. Major aspects of an arrangement subsystem incorporate both profound center convictions and strategy center convictions. The deep core beliefs of a policy subsystem are reflected in official statements about general assumptions about human nature, priority fundamental values, priority groups for welfare, the job of government versus the market as a general rule, and who ought to take part in government dynamic. [4]

\subsection{ACF Model from Sabatier and Colleagues}

This study uses the ACF version of Sabatier and Jenkins-Smith 1998. The author's reason is that the ACF version of Sabatier and Jenkins-Smith 1998 has been explored for its application in developing countries. In Indonesia, empirical research on the possible application of the 1998 variant of the ACF of Sabatier and JenkinsSmith has been carried out for forest policy by Chris Elliot and can be applied without difficulty. The ACF version of Sabatier and Weible 2007 has not been investigated for its possible application in Indonesia. Based on these reasons, this study uses the version of ACF Sabatier and Jenkins-Smith 1998. ACF has several core components that are interrelated with one another These components are the measurement of a relatively stable system, external conditions, and policy subsystems. ACF assumes that most of the policy process is closely related to the policy subsystem. The sectors that make policies together and in synergy constitute a national policy system so that each policy in each of these sectors is called a policy subsystem. [5]

\subsection{Land Registration Policy}

\subsubsection{National Agrarian Operations Project (PRONA)}

A program in asset legality can be implemented with the National Agrarian Operations Project or known as PRONA, which is the implementation of land administration starting at the adjudication stage, land registration until the issuance of confirmation of responsibility for or different privileges in the form of a certificate which is carried out simultaneously. PRONA has also become the government's choice in the context of the welfare of the people whose economy is classified as weak to medium.

PRONA is an approach made by the public authority in the defense sector through the National Land Agency, especially in terms of land enlistment which is completed at the same time and can resolve strategic rights disputes.

\subsubsection{Complete Systematic Land Registration (PTSL)}

The rules relating to PTSL are contained in the Guideline of the Minister of Agrarian Affairs and Spatial Planning/National Land Agency of the Republic of Indonesia Number 12 of 2017. In the guideline, there is an article which states that PTSL has a goal as an acceleration in providing legal certainty and protection based on land that belongs to the community through simple, clear, fast, and transparent procedures that meet the elements of security, justice and can be accounted for so as to provide increased trust community, quality of life and economic prosperity of the community. In addition, it can reduce and avoid land disputes.

A plot of land that is measured and mapped in a completely systematic manner which is grouped into one urban village/village in full, has the following objectives:

1) The time required is quite fast than doing it sporadically;

2) Make it easier for measuring officers in terms of direction and regulation;

3) Knowing at the same time land plots that were not previously registered in an urban village/village area; 
4) Knowing at the same time the plot of land that is in dispute or conflict in an urban village/village area;

5) One-sided boundaries can be agreed upon more easily with the principle of contradictory delimitation;

6) At the same time, updating map data as a basis for land registration.

\section{METHOD}

The research method used is through a qualitative approach; researchers go to the field to collect data in a natural context, researchers interact with subjects/participants to gain their perspective in the real world. All these field activities are oriented to provide a detailed description of the phenomenon of land registration policy change in Makassar City. The perspective of the participants, the nature of data collection, fieldwork, and the richness of description are all key characteristics of qualitative research.

This review utilizes various information sources, as is normal in subjective exploration. Most subjective review references recognize three primary wellsprings of information for subjective exploration, namely the results of interviews, observations, and supporting files. This data collection comes from the results of interviews with selected participants, activity documents, and direct observations. The utilization of various information sources is significant on the grounds that it permits triangulation methodologies to be applied to work on the legitimacy of study discoveries.

Primary data sources come from informants who are involved in the implementation of the policy technically and who are in charge of the policy. Profiles of resource persons who can assist researchers are those who have experience working as land registration managers for at least the last six months. The informants in this research are the Head of Land Rights and Land Registration Division of the Public Land Agency of South Sulawesi Province; Head of Infrastructure Section of the Makassar City National Land Agency; PTSL Team Leader 2020 Makassar City; South Sulawesi Regional Agrarian Reform Consortium; Community.

Analysis of the data obtained in this study uses steps based on the theory of Miles, Huberman, Saldana, namely data analysis based on three stages: data selection and transforming the data (condensation), preparing data to be presented (data display) and making conclusion and validation. Data condensation consists of the process of selection, centralization, simplification, summarization, and data transformation. [6]

\section{FINDINGS AND DISCUSSION}

The results of research interviews also, optional information got in the field will be discussed in this section. The discussion is in accordance with what has been stated in the previous section, namely the Change of Land Registration Policy in Makassar City.

The Makassar City National Land Agency provides views on the change in the land registration policy from PRONA (National Agrarian Operations Project), which is regulated in the Regulation of the Minister of Agrarian Affairs and Spatial Planning/National Land Agency Number 4 of 2015 to Complete Systematic Land Registration (PTSL) which is confirmed through a Ministerial Regulation Agrarian and Spatial Planning/National Land Agency Number 6 of 2018 concerning Complete Systematic Land Registration. According to his statement, both PRONA and PTSL are the same program regarding land adjudication, but there are only slight additions to the results to be achieved later. Not only producing land certificates but also carrying out a mapping process to improve data on land in Indonesia, which are grouped into several categories.
"Actually, the same thing between Prona and PTSL, according to Government Regulation No. 24 of 1997, these two programs are the same, namely regarding land adjudication. It's just that there is a slight increase in the results to be achieved which are not only producing certificates but carrying out a mapping process to improve data on lands in Indonesia, which will then be grouped into several categories." (Head of the Division of Rights and Registration of the National Land Agency of South Sulawesi Province).

In the PRONA and PTSL programs which are systematic land registration policies, the only difference is the Regulation of the Minister of Agrarian Affairs and Spatial Planning/National Land Agency Number 6 of 2018, aimed explicitly at PTSL issues. So, in general, there is no difference between PRONA and PTSL, which has slightly changed. The current PTSL Decree can be issued directly by the Head of the Regional Office of the National Land Agency. Changes also occur related to acceleration, namely regarding officials who signed the Decree on the appointment of a task force which initially came from a Ministerial Decree. Now with Ministerial Regulation Number 6 of 2018, a Decree on the selection of locations and implementation can be issued by the Head of the Regional Office of the National Land Agency. Furthermore, the announcement time on the PTSL program is shortened to 14 days.

Changes of land registration policy from PRONA (National Agrarian Operations Project), which is managed in the Regulation of the Minister of Agrarian Affairs and Spatial Planning/National Land Agency Number 4 of 2015 to Complete Systematic Land Registration (PTSL) which is confirmed through the 
Regulation of the Minister of Agrarian and Spatial Planning/National Land Agency Number 6 of 2018 concerning Complete Systematic Land Registration. According to the regulation, both PRONA and PTSL are the same program, namely regarding land adjudication, and there is only a slight increase in the results to be achieved later, which is not only to produce a certificate but also to carry out a mapping process to improve data on land in Indonesia which is grouped into several categories.

It is known that since the $1960 \mathrm{BAL}$, where it is the government's obligation to register land, there has been, and then in 1980, the PRONA program has existed. However, PRONA programs are generally only sporadic or not comprehensive in one area. Then from these facts seen in the field in 2017 by the government, which is included in the auto critic section, in other words, this program is irrelevant when it comes to fulfilling obligations in implementation of land registration as per Article 19 of the Basic Agrarian Law; therefore it is enlarged through the PTSL Program. The PTSL program is carried out with a registration system that is carried out systematically and no longer talks sporadically and no longer talks from one field to another. But in one area the whole in one urban village.

PRONA and PTSL are not different and are only limited to the issue of regime differences, each of which shows its own characteristics; it is known that in the period of President Susilo Bambang Yudhoyono, it was called PRONA, and in the era of President Jokowi it was called PTSL which seems to give the impression that this agrarian reform is being implemented under Jokowi's regime and has not been implemented in the previous leadership era.

"So actually, if you want to talk about Prona and PTSL, in our view, there is no difference. Because in our opinion, this is only a matter of the regime which wants to show that this regime has its characteristics. In the era of President SBY, it was called Prona, and in the era of President Jokowi, it was called PTSL. The impression is that this agrarian reform was implemented under President Jokowi's regime and had not been implemented in the previous leadership era. What happened was tinkering with names to give the impression that the PTSL policy was different from the previous one. The problem that becomes an obstacle in implementing agrarian reform is the government's perspective in dealing with issues. During the time of President SBY or the era of President Jokowi, they saw the problem of agrarian reform, namely how to give certificates to the public; that was what they saw as the main problem. The solution is not giving a certificate, but the solution is to redistribute land to the community fairly. At the same time, the issue of agrarian reform is how inequality exists in land ownership by the community." (South Sulawesi Agrarian Reform Consortium).

There is no difference between PRONA and PTSL, and it is only a matter of regime differences, each of which shows its characteristics. It is known that during the time of President Susilo Bambang Yudhoyono, it was called PRONA. In the era of President Jokowi, it was called PTSL, which seems to give the impression that this agrarian reform is being implemented. Under Jokowi's regime, and has not been implemented in the previous leadership era.

Data from the National Land Agency (BPN) of the Republic of Indonesia there are as many as 126,000,000 plots of land in Indonesia, but as of 2016, only about $46 \%$ of newly registered land plots. So there are still around 86 million lands whose ownership is not clear or does not yet have a certificate. Based on that data, the President of Indonesia always voiced during his speech at the beginning of his position when visiting each region that the problem of land disputes was a serious problem so that a strategic policy was needed to develop and carry out reforms in the agrarian sector to become a focus in the government. Until 2017, more than $50 \%$ of land plots in Indonesia had no clear ownership status and had the potential for disputes. Land registration is the most important thing, but the community still does not understand it, so that there are still many lands owned by the community but have not been registered so that they do not have certificates which must be due to various reasons so that people do not register their lands. One of these factors is the perception of the community that if they want to register their land in order to get a certificate, it takes a long time and the registration process is quite difficult, and the costs incurred are quite expensive.

In the era of President Joko Widodo's administration from 2014 to 2019, many ministers were replaced in the Working Cabinet of that period, including the Minister of Agrarian Affairs, so that a rule change was made, namely Guideline of the Minister of Agrarian Affairs/National Land Agency number 3 of 1997 with regards to the execution arrangements of the Government Number 24 of 1997 with regards to Land Registration as referred to in paragraph has been amended by Guideline of the Minister of Agrarian Affairs/National Land Agency Number 8 of 2012 with regards to revisions to the Regulation of the Minister of Agrarian Affairs/National Land Agency Number 3 of 1997 with regards to arrangements for carrying out Government Regulation Number 24 of 1997 with regards to Land Registration. The regulation related to the registration of land rights registration was then replaced with a new rule, to be specific the guideline of the Minister of Agrarian Affairs and Spatial Planning/Head of the National Land Agency Number 12 of 2017 concerning the Acceleration of the Implementation of Complete Systematic Land Registration (PTSL) and subsequently used as a government activity program in order to make it simpler 
for the general population to get land declarations, previously known as the PRONA, which became the program of the previous president, Susilo Bambang Yudhoyono.

The definition of PTSL based on the Guideline of the Minister of Agrarian Affairs and Spatial Planning/National Land Agency Number 12 of 2017 in article 1describes the definition of land registration as the stages of actions carried out by the government in a sustainable manner and as per pertinent guidelines. The phases of the action start from collecting, managing, keeping books, introducing and keeping up with both physical and juridical information in the structure of lists and maps of each plot of land, house, and other rights, including providing proof of ownership of privileges for bundles of land that as of now have freedoms.

The policy was initiated because of a public problem that must be resolved; therefore, the government makes a definite and clear policy and legal basis so that it is implemented to solve problems related to land or community rights.

Anderson argues regarding public policy; there are groups of parties who have more privileges than others. Public policy in every implementation will be affected by the interests of the dominating group. During the process of drafting the policy concept, from an economic and political perspective, the parties involved will face various choices, which trigger the desire to obtain maximum benefits. This statement is in line with the idea conveyed by Easton, where public policy has a character that begins with the concept of a formula drawn up by the power holders of the political system, including the highest elders of a tribe, executive council, legislature, judiciary, administrators, advisors, kings and so on. According to Easton, this position is "the position of a person who relates to the daily dynamics of the political system," or better known as the dominant member in the system with responsibility and authority in policymaking. [3]

\section{CONCLUSION}

The conclusion that the researcher can convey is that from the previous explanation regarding the Change of Land Registration Policy in Makassar City, the change from PRONA to PTSL occurred not because of the idea of an advocacy coalition but only a government drive in the Regulation of the Minister of Agrarian Affairs and Spatial Planning/National Land Agency Number 3 of 1997 which examines the Provisions for the Implementation of Government Regulation Number 24 of 1997 with regards to Land Registration as revised dependent on the Regulation of the Minister of Agrarian Affairs and Spatial Planning/National Land Agency Number 8 of 2012 about amendments to the Regulation of the Minister of Agrarian Affairs and Spatial Planning/National Land Agency Number 3 of 1997 concerning Provisions for the Implementation of Government Regulation Number 24 of 1997 concerning Land Registration. This is related to the Amendment to the Legislation regarding the Registration of Land Privileges as expressed in the Agrarian and Spatial Planning/National Land Agency Number 12 of 2017 with regards to Acceleration of the Implementation of Complete Systematic Land Registration (PTSL). The PRONA and PTSL policies are the same policy, namely regarding land adjudication; there is only a slight increase in the results to be achieved later, which is not only to produce a certificate but also to carry out a mapping process to improve data on land in Indonesia which is grouped into several categories.

Suggestions from researchers are: (1) The government should build cooperation with any party in order to provide a common understanding and perspective among planners, policymakers, and implementers in changing land registration policies in Makassar City. (2) Massive socialization, both directly and indirectly, regarding systematic changes in land registration policies

\section{REFERENCES}

[1] Peraturan Pemerintah Nomor 24 Tahun 1997 tentang Pendaftaran Tanah

[2] Sabatier, P.A., Jenkins-Smith, H. The Advocacy Coalition Framework: Innovations and Clarifications. In Theories of the Policy Process, the second edition, edited by Paul A. Sabatier. Boulder, CO: Westview Press, 2007. 189-221.

[3] Anderson, James E. Public policymaking: an introduction $8^{\text {th }}$ ed. USA: Cengage Learning, 2015.

[4] Sabatier, P.A. The need for better theories. in theories of the policy process, edited by Paul A. Sabatier. Boulder, CO: Westview Press, 2007. pp. 3-20.

[5] Sabatier, P.A. and Weible, C.M. The Advocacy Coalition Framework: Innovations and Clarifications. In Sabatier, P.A., Ed., Theories of the Policy Process. CO: West Press, 2007. 189220.

[6] Miles,M.B, Huberman,A. M, and Saldana, J. Qualitative data analysis, a methods sourcebook, edition 3. USA: Sage Publications, 2014 